\title{
Operation ballast water of commercial vessels in Port of Tanjung Emas Semarang
}

\author{
Agus Tjahjono ${ }^{1, *}$, Wisnu Handoko ${ }^{2}$, Sri Purwantini ${ }^{3}$ \\ ${ }^{1}$ Politeknik Ilmu Pelayaran Semarang, Indonesia
}

\begin{abstract}
The commercial vessel uses sea water to stabilty a vessel when the vessel is not loading a cargo. The water stabilized for the vessel is known as ballast water. The activity of loading the ballast water for the ship from origin port and dissposal to the distination port has caused impact on spreading the unidenfied organism the local port. Aim of the study to determine disposal value of water ballast either from a foreign merchant vessel or domestic merchant vessel so that Port of Tanjung Emas Semarang (PTES) is able to determine a policy on ballast administration from merchant vessel include a data of Arrival and Departure Report of the Vessels (ADRV) documents for the last five years (2009-2014). Disposal ballast water of domestic vessel to PTES is average about $37,036 \mathrm{~m}^{3}$ and increased by $76.68 \%$ in a year. Yearly ballast water disposed from the foreign commercial vessels has reached $576.045 \mathrm{~m} 3$ for the last 5 years. The increasing of ballast water is about $122.19 \%$. Level of vunerability on the PTES waters is due to ballast water dissposal caused mainly from foreign commercial vessels. The PTES administration should provide water reservoir and and water ballast treatment of commercial vessels which has $51,090 \mathrm{~m}^{3} / \mathrm{per}$ month or $81,744 \mathrm{kl} /$ month.
\end{abstract}

\section{Introduction}

A commercial vessel, its operation uses sea water which is kept in ballast tank to maintain vessel's stability. When the cargo is empty, a commercial vessel will suct sea water from port area and it will dischrage sea water in ballast tank after reaching the next port.

Ballast water system in commercial vessel uses Ballast pump to unload or load sea water in ballast tank. In addition to increase ship's stability, sea water in ballast tank is used to get the desirable draft of a vessel, increase speed, change trim, decrease bending moment, control list during loading and unloading the cargoes and increase the vessel's manouver [1].

Water ballast which is discharged by the commercial vessels to destination port has an effect on aquatic environment, the effect at the east cost of Rhode Island has expanded invasion sea weed, migration of jellyfish, Turritopsis dohrnii at seashores in Atlantik and Passific in Panama, Florida. Origin of far away land, Italia, Mallorca, Spain, Okinawa,

\footnotetext{
* Corresponding author:
} 
Panama Coast, have spreaded VHSV virus in 55 fish species in fish at Great Lake waters [2-4].

The impact of ballast water dicharge is also found Asian shrimp Palaemon macrodactylus at east cost of US and New York estuaries in 2001. Moreover a female shrimps which is carry the eggs is found (2001-2002, and 2008) showing the shrimps her doubled [5].

International Maritime Organization (IMO) has legalised a rule of ballast water of commercial vessel via Ballast Water Management Convention in 2004. One of the preliminary requirement is D 1 standard or first standard. It stated that vessel must exchange ballast water in the mid sea ocean range 200 mil before entering distination port or at a depth of at least $200 \mathrm{~m}$ in order to minimize spread of the hazard organisms in waters $[6,7]$.

There are three methods of ballast water exchange as follows the sequential method (the process with the emptying of the ballast water and recharged to obtain at least $95 \%$ volumetric exchange), the flow-through method (the process of replacing the ballast water so that water out through overflow or other arrangement), the dilution method (the process of replacing the ballast water filled through the top of the ballast tank with the simultaneous discharge from the bottom of the tank) [7].

The purpose of this study is to analyze the volume of the ballast water of commercial vessels disposal coming to PTES waters for a period of five years and to provide data to PTES administrator to formulate the volume of supply and storage of ballast water from commercial vessels at PTES as the cheapest option in the management of ballast water from commercial vessels.

\section{Material and methods}

Ballast water capacities are calculated for each commercial vessel witth Dead Weight Ton (DWT) more than 400 Gross Tonnage (GT) arrived at PTES waters according to the result from IMO for general cargo vessel $36,5 \%$, bulk cargo $35 \%$, liquid cargo $35 \%$, container $30 \%$, mixed cargo 33\%, and Roll on Roll off (Ro-Ro) 33\% from DWT [8-10]. Source of incoming and out going commercial vessels from PTES waters used source of Arrival and Departure Report of the Vessels (ADRV) from port harbour administration and harbour otority (KSOP) Tanjung Emas Semarang for the last five years from 2009 to 2014 [11]. PTES is managed by PT. Pelindo III at central Surabaya, and has a management area covering ports of Banjarmasin,Benoa, Samarinda, Cilacap, Padang Bai, Lembar [12]

The discharge of ballast water from a commercial vessel is known from the vessel to unload or load the cargo. If the vessel unload all cargoes in a port then to arrange the draft, either the bow or stern, the vessel has to ballasting of sea water at the port to compensate for the vessel even keel event (there is no big difference between the bow and stern draft). Whereas if the vessel loads to the entire hatch or existing cargo space, the vessel must deballast the seawater (from the port of origin to the loading port) to compensate for the cargoes.

\section{Results and discussion}

The domestic commercial vessel berth at PTES in 2009, DWT is about 693,470 MT, maximum DWT accumulation was on October whereas the minimum was on November. It's appropriate to its capacities of ballast tank there at the same month has experienced the maximum and minimum condition. Discharge ballast for each month reached 4,089.75 $\mathrm{m}^{3}$ with the minimum dispossal on February $\left(1,286 \mathrm{~m}^{3}\right)$, maximum on October $\left(8,121 \mathrm{~m}^{3}\right)$. 
There have been any increased disposal ballast water as $60.64 \%$ in 2009 . The arrival commercial vessels at PTES on November are at minimum (70 vessels) which is the smallest vessel is about (533,990 MT) and the smallest capacities are (186,080 MT), because there were more vessel loading the cargoes, there was more ballast water dispossal $\left(6,088 \mathrm{~m}^{3}\right)$ (Figure 1 a. )
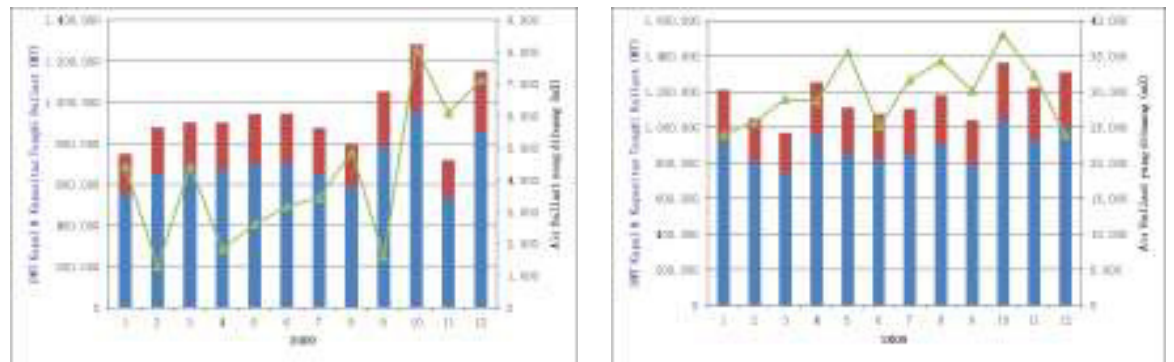

Fig. 1. DWT, ballast tank capacities and ballast water discharge of commercial vessels from a) domestic b) foreign in 2009 (DWT> 400 MT, exclude barge and tug boat)

The foreign commercial vessels coming to PTES have fewer numbers than domestic vessels, where the number of foreign commercial vessels are a maximum of 69 compared to 112 vessels. However, the average foreign vessels's DWT is $884,293.67$ MT compared to domestic vessels of 693,470 MT. It also has implications for larger vessel ballast capacities at an average of 274,870 MT. The average monthly ballast water discharged per month is $29,9915 \mathrm{~m} 3$, a minimum of $23,978 \mathrm{~m} 3$ in January, and a maximum of $38,070 \mathrm{~m} 3 \mathrm{in}$ October which shows the vessels the most loading cargoes compared to unload.During the year there was no increase in ballast water discharges to PTES (Figure1 b.).

The monthly average of vessels entering PTES weigth 852,900 MT with the minimum month of February (599,398 MT) and the maximum in September $(1,072,708$ MT), it is proportional to the number of ships coming to PTES where in February there were only 74 and September 114 vessels. The implications of the number of ship DWT to PTES are the vessels's ballast capacities, minimum 206,779 MT (February) and maximum 370,448 MT (September), with monthly average ballast capacities of 295,184 MT. The discharge of ballast water to PTES is different from DWT condition and vessels's ballast tank capacities, which in May experienced maximum discharge $(8,862 \mathrm{~m} 3)$ and January minimum $(802 \mathrm{~m} 3)$ with monthly discharge of 3,291 m3. For domestic vessels in 2010, an increase in DWT and vessels's ballast tank capacities came in at $21.80 \%$ while for the discharge of ballast water to PTES there was an increase of $139.53 \%$ starting from the beginning of the month until December (Figure 2 a) .
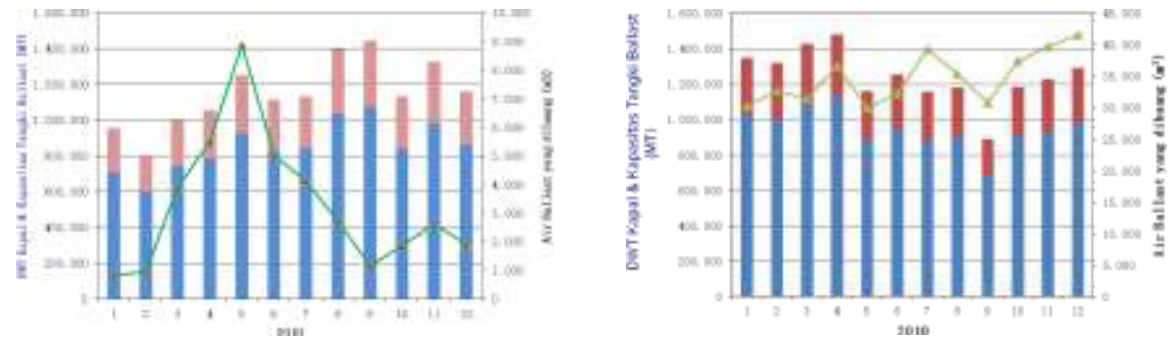

Fig.2. DWT, ballast tank capacities and ballast water discharge of commercial vessels from a) domestic b) foreign in 2010 (DWT> 400 MT, exclude barge and tug boat) 
In April 2010, foreign's commercaial vessel DWT and ballast tank capacities coming to PTES experienced a maximum condition of 1,130,451 MT and 353,430 MT respectively, minimum in September with DWT vessels of 677,596 MT and ballast tank capacities of 212,693 MT. The vessel that discharges the ballast water experienced a maximum condition in December of 41,590 m3, the minimum month of May of 29,917 m3 and the monthly average of ballast water discharge of $34,776 \mathrm{~m} 3$. Foreign vessels coming to PTES in 2010 are decreasing, it can be seen from DWT and its ballast tank capacities are $3.71 \%$ and $6.08 \%$ respectively. However, for the discharge of ballast water from foreign vessels increased by $37.36 \%$, it was due to an increase in the loading of cargoes for export (Figure 2 b.).

Domestic vessels entering the PTES in 2011 amounted to 1227 vessels, a maximum of 121 in December and a minimum of 84 vessels in February. The average domestic's vessels DWT for the entire year are 982,561 MT, with maximum conditions in August $(1,114,851$ MT), the minimum month of February being 865,342 MT. DWT and domestic's vessel ballast tank capacities are increased by $10 \%$. It is proportional to the ballast tank capacities of 385,152 MT and 299,554 MT. Ballast water discharged to PTES on average is 2,367 $\mathrm{m} 3 /$ month, with maximum conditions in October and March of 4,605 m3 and 1,518 m3. Ballast water discharges by domestic commercial vessels to PTES increased by $44.62 \%$ (Figure 3 a.)
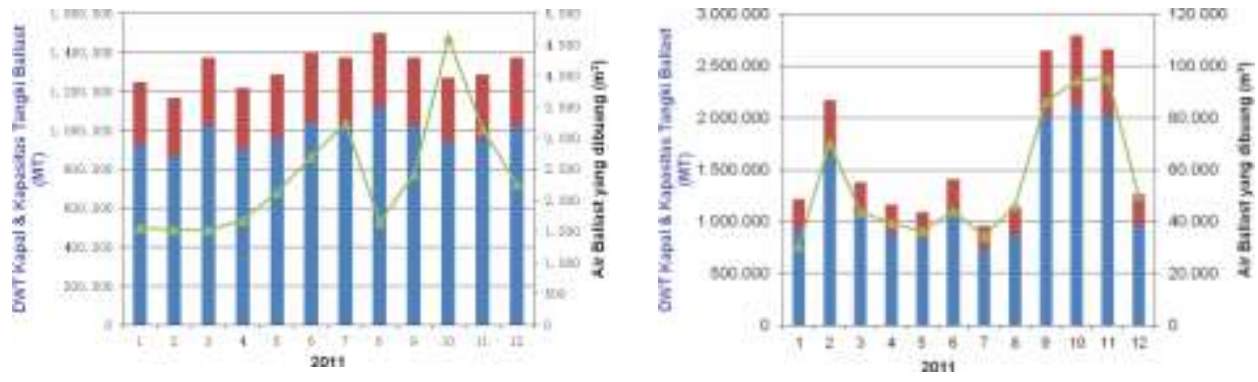

Fig. 3. DWT, ballast tank capacities and ballast water discharge of commercial vessels from a) domestic b) foreign in 2011(DWT> 400 MT, exclude barge and tug boat)

Foreign commercial vessels coming to PTES with DWT average of 1,265,368 MT in 2011, with maximum and minimum conditions in October $(2,126,581 \mathrm{MT})$ and July $(734,683 \mathrm{MT})$, DWT of the arrival vessels increased by $3,94 \%$. The average capacities of the ballast water during the entire year amounted to 395,082 MT with maximum and minimum conditions of 667,499 MT and 225,446 MT respectively. Ballast water discharge to PTES waters increased by $64.26 \%$, with maximum and minimum conditions of 95,619 $\mathrm{m} 3$ and 30,561 m3 occurring in November and January. Average monthly ballast water disposal during the year by foreign vessels are 55,914 $\mathrm{m} 3$ (Figure $3 \mathrm{~b}$.).

Domestic commercial vessels with an average DWT of 872,448 MT while maximum and minimum DWT conditions in May and June of 966,248 MT and 784,227 MT. This is in line with the ballast tank capacity of 333,989 MT and 270,489 MT. Ballast water discharges from domestic vessels in the average of $4,113 \mathrm{~m} 3 / \mathrm{month}$ with an increase of 7.84\% (Figure 4 a.). 

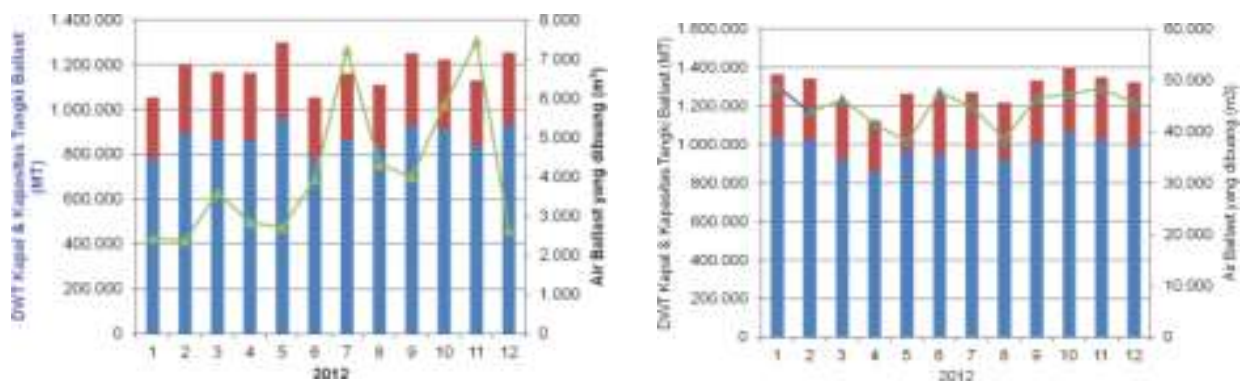

Fig. 4. DWT, ballast tank capacities and ballast water discharge of commercial vessels from a) domestic b) foreign in 2012(DWT> 400 MT, exclude barge and tug boat)

The average DWT and ballast tank capacities of foreign vessels coming to PTES amounted to 978,757 MT with maximum and minimum DWT in October and April. There was decrease of foreign vessels arrival these year is indicated by the decrease of average vessels's DWT by $3.9 \%$. In line with this, the ballast water discharged by foreign vessels also decreased $6.68 \%$. Average ballast water disposed of $44,783 \mathrm{~m} 3$, with maximum discharge conditions in January and minimum in August (Figure 4 b.)

Domestic commercial vessels berthing on PTES with average DWT of 934,149 MT/month with an increase of DWT from the beginning of the month of $20.32 \%$. The arrival of the vessels reached a maximum number of 143 vessels in September with DWT 1,119,560 MT with the ballast tank capacities of 385,250 MT. While the minimum conditions occurred in February, where there were vessels visits of 103 vessels with DWT $738,975 \mathrm{MT}$ and ballast tank capacities of 251,028 MT. Increased ballast water discharged by domestic vessels is small at $1.33 \%$, with maximum disposal in February and a minimum in June (Figure 5 a.).
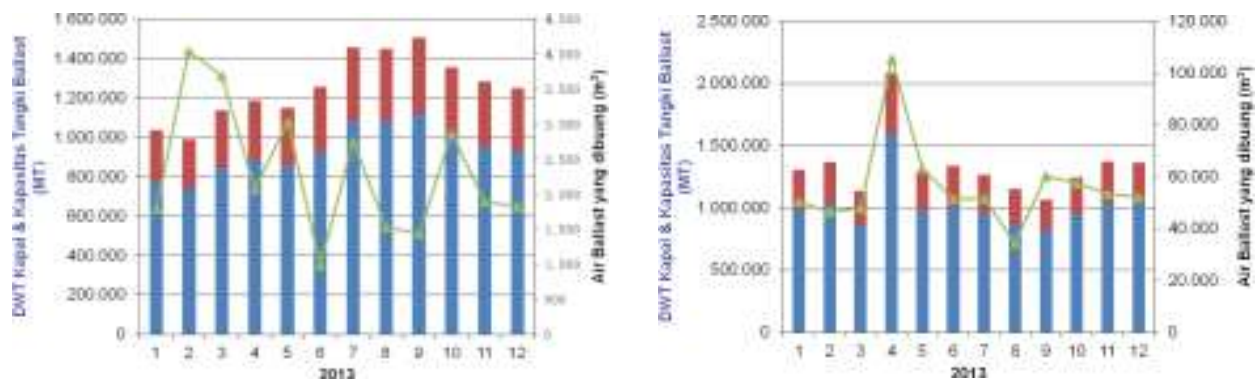

Fig. 5. DWT, ballast tank capacities and ballast water discharge of commercial vessels from a) domestic b) foreign in 2013(DWT> 400 MT, exclude barge and tug boat)

Foreign commercial vessels coming to PTES totaling 676 vessels with a mean dead weight of 1,011,526 MT, with April experiencing maximum conditions and the minimum September of 1,589,247 MT and 813,035 MT respectively. In line with the dead weight of the vessel, the tank capacities of the ballast water also follows where it has experienced maximum and minimum conditions in the same month. Ballast discharges from foreign vessels average 56,165 m3, maximum in April (105,338 m3) and August (34,479 m3). Increased discharge of ballast water from the beginning of the month was small at value $3.34 \%$ (Figure 5 b.).

The dead weight of domestic commercialvessels coming to PTES with an average of 934,149 MT, an increase in ship arrival by $20 \%$ from the beginning to the end of the month. The domestic's vessels arrival of totaling 143 vessels, the deadweight and ballast water 
capacities in September became the maximum (1,119,560 MT and 385,250 MT). However, this condition does not apply to ballast water discharges, due to the most loaded vessels, experiencing maximum conditions in February with a value of 4,044 m3, and a minimum in May $(990 \mathrm{~m} 3)$. The discharge of ballast water into PTES waters was a relatively small increase of only $1.33 \%$ (Figure 6 a.).
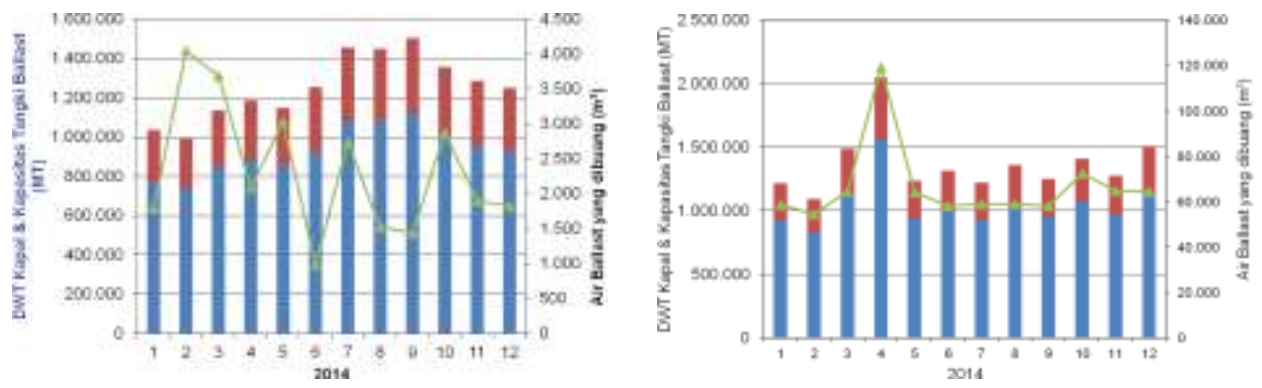

Fig. 6. DWT, ballast tank capacities and ballast water discharge of commercial vessels from a) domestic b) foreign in 2014(DWT> 400 MT, exclude barge and tug boat)

DWT of foreign vessels ranging from 830,170-1,564,907 MT with maximum and minimum conditions occurring in April and February, the vessels's dead weight coming to PTES increased $23.7 \%$ from the beginning of the month. While the vessels's ballast capacities are also proportional to the dead weight of foreign vessels ranging from 261,111482,097 MT. The ballast water discharge experienced an increase of $9.63 \%$ with the maximum and minimum conditions occurring in April and February, where the average of ballast water discharged into PTES was $66,467 \mathrm{~m} 3 /$ month (Figure 6 b.).

The number of domestic and foreign commercial vessels arriving to PTES from 20092014 where for domestic merchant vessels ranges from 1043 to 1408 vessels, with the average of 1236 vessels/year. The foreign vessels coming to PTES are smaller, ranging from 676-1045 vessels with an annual average of 768 vessels. The arrival of domestic and foreign vessels to PTES during 5 years increased where for domestic ships $35 \%$ while overseas ships were $54.6 \%$ (Figure 7 .).

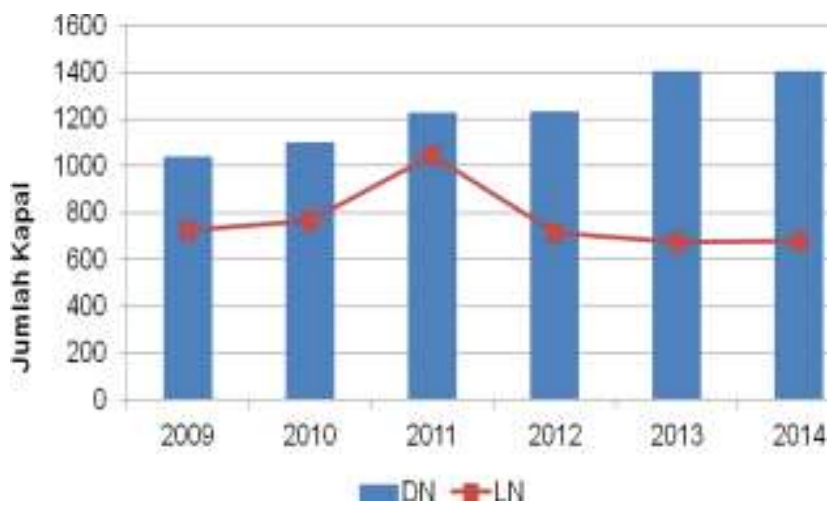

Fig. 7. Recapitulation the numbers of commercial vessels from domestic and foreign at PTES

DWT of domestic vessels coming to PTES for 5 years ranged from 8,321,640$11,790,736$ MT with an increase of $41.69 \%$. This is proportional to the number of domestic vessels arrivals which increased by $35 \%$. The average ballast water discharge of domestic 
vessels in PTES is 37,036 m3/year, ranging from 27,937 $\mathrm{m} 3$ to $49,360 \mathrm{~m} 3$ during the same time period which has increased by $76.68 \%$ (Figure 8 .)
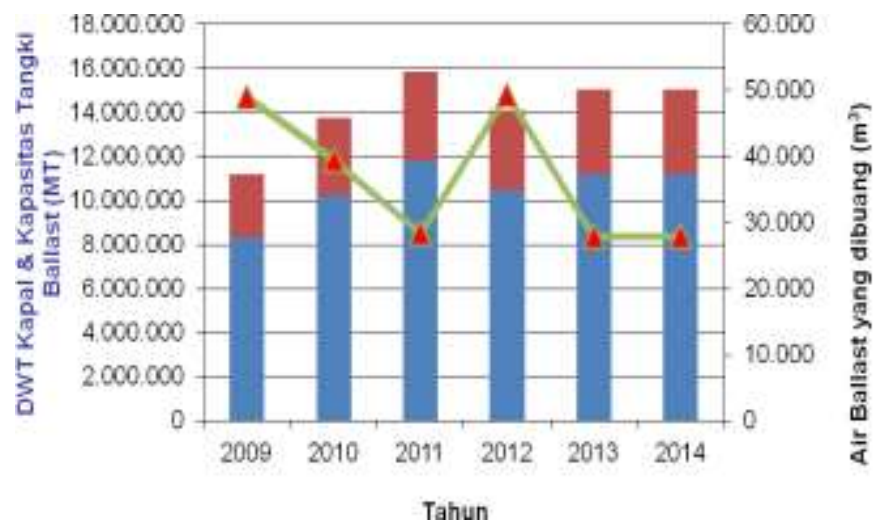

Fig. 8. Recapitulation of DWT, ballast tank capacities and ballast water discharge of domestic vessels at PTES (2009-2014)

The dead weight of foreign vessels coming to PTES ranges from 10,611,524 MT$15,184,422$ MT with an average DWT of 12,257,847 MT/year. There was an increase during 5 years period of 5 years in foreign vessels arrival and dead weight in PTES amounting to $54.59 \%$ and $43.09 \%$, respectively. In line with this, the capacities of the ballast water also increased with the same value. The average annual ballast water discharge of the foreign vessels within that period reached $576,045 \mathrm{~m} 3$, with the maximum and minimum discharges in 2014 and 2009. There was a significant increase of ballast water discharge by foreign vessels by $122.19 \%$. This shows that foreign vessels coming to PTES are more cargo loading for export (Figure 9.).

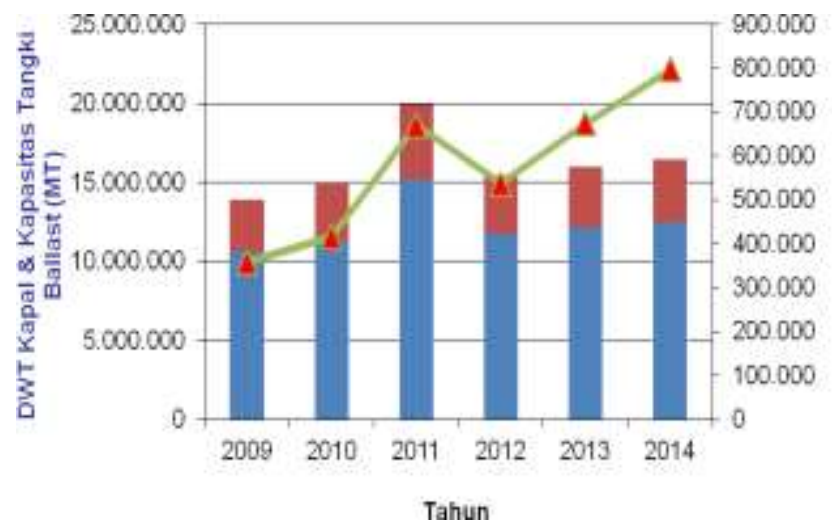

Fig 9. Recapitulation of DWT, ballast tank capacities and ballast water discharged of foreign vessels at PTES (2009-2014)

Effectiveness level of mid ocean ballast water exchange rates shows a decrease in Skeletonema costatum abundance on container vessels entering to Hong Kong port from California waters, a decrease in abundance of diatoms and dinoflagellates on commercial vessels originating from Mexico [13, 14].

The strategy undertaken by the European shipping community in response to the Ballast Water Management (BWM) Convention is to enforce this Convention as a temporary 
solution despite its limited effectiveness, in collaboration with agencies developing BWM Convention in Europe to help harmonize BWM requirements across Europe [15]. The study of the effectiveness of mid ocean ballast water exchange shows the greatest exchange occurs when the source of sea water comes from the port with a low salinity and the exchange will be effective when it occurs in deeper waters than the land, so the ballast water exchange does not discharge all taxa from the port of origin and unsuitable in a regional ballast water setting [16].

\section{Conclusion}

DWT of domestic's commercial vessels coming to PTES for 5 years ranges from 8,321,640 to $11,790,736$ MT with an increase of $41.69 \%$. The average of ballast water discharge to PTES is $37,036 \mathrm{~m} 3 /$ year, an increase of $76.68 \%$. Arrival of domestic and foreign vessels to PTES during 5 years has increased where for domestic ships $35 \%$ while overseas ship $54.6 \%$ The weight of foreign commercial vessels coming to PTES are about 10,611,524 MT-15,184,422 MT. The average ballast water discharge of foreign vessels within 5 years reaches $576,045 \mathrm{~m} 3 /$ year. The significant increase of ballast water disposal by foreign vessels are $122.19 \%$.

The vulnerability level of PTES waters due to ballast water disposal is mostly caused by foreign vessels compared to domestic vessels due to the foreign vessels more load cargoes compared to domestic vessels.

The administrator of PTES should provide a reception and ballast water treatment facilities from a commercial vessel with a capacity of $51,090 \mathrm{~m} 3 / \mathrm{month}$ or 81,744 $\mathrm{kl} / \mathrm{month}$.

\section{Acknowledgment}

The authors would like to thank the authority of Port of Tanjung Emas Semarang (PTES) who has provided data especially Mrs. Erry. The authors also thank Mr. Slamet Riyadi who has helped in the formulation of the method of calculating the capacities of ballast water output. Thanks to the vessel's officer to the author who has authorized the ballast vessel ballast tank inspection.

\section{References}

1. Van Dokkum, K., Ship knowledge covering ship design, construction and operation : E 2, Dokmar, Enkhuizen. (2005).

2. Villalard-Bohnsack, M., and M. Harlin, Grateloupia doryphora halymeniaceae, rhodophyta) in Rhode Island waters (USA), geographical expansion, morphological variations and associated algae, Phycologia ProQuest, 40, 4, pg. 372. (2001).

3. Miglietta, M.P., and H.A Lessios, A Silent invasion, Biology Invasion, 11:825-834. DOI 10.1007/s10530-008-9296-0. (2008).

4. La Rue, E.C., C.R., Ruetz III, M.B. Stacey, and R.A. Thum, Population genetic structure of the round goby in Lake Michigan : implications for dispersal of invasive species, Hydrobiologia, 663, 71-82, DOI 10.1007/s10750-010-0555-6. (2011).

5. Warkentine, B.E., and J.W. Rachlin, The first record of Palaemon macrodactylus (oriental shrimp) from the eastern coast of North America, Northeastern Naturalist, 17, 1, pg.91., ProQuest. (2010). 
6. IMO (International Maritime Organization). International Convention for The Control and Management of Ship's Ballast Water and Sediments, 2004. International Maritime Organization, London, p 36. (2005).

7. IMO (International Maritime Organization). Guidelines for Ballast Water Exchange (G6). Annex 2, Resolution MEPC.124 (53). Adopted on 22 July. (2005).

8. IMO (International Maritime Organization), Guidelines for ballast water management and development of ballast water management plans ( $\mathrm{G} 4)$, International Maritime Organization, London, adopted on 22 July 2005, Resolution MEPC.127.53. (2005).

9. Butron, A., Orive, E., and I. Madariaga, Potential risk of harmful algae transport by ballast waters : the case of Bilbao harbor, Marine Pollution Bulletin 62, page 747-757. DOI : 10.1016/j.marpolbul.2011.01.008. (2011).

10. David, M., Perkovic, M., V. Suban, and Gollasch, S, A generic ballast water discharge assessment model as a decision supporting tool in ballast water management. Decision Support Systems 53, page 175-185, DOI: 10.1016/j.dss.2012.01.002. (2012).

11. KAPTES (Kantor Administrasi Pelabuhan Tanjung Emas Semarang), Data kegiatan angkutan laut dalam dan luar negeri di pelabuhan Tanjung Emas Semarang tahun 2009-2014, Bidang Lala dan Kepelabuhanan, Kantor Administrasi Pelabuhan Tanjung Emas Semarang. (2011).

12. PT. Pelabuhan Indonesia III (Persero) Cabang Tanjung Emas, Tanjung Emas port directory, Surabaya, Dwitama Wukirindo. (2011).

13. Zhang, F. and Dickman, M., Mid-ocean exchange of container vessel ballast water 1 : seasonal factors affecting the transport of harmful diatoms and dinoflagellates, Marine Ecology Progress Series, Vol. 176, page 243-251. (1999).

14. Dickman, M. and Zhang, F., Mid-ocean exchange of container vessel ballast water 2 : effects of vessel type in the transport of diatoms and dinoflagellates from Manzanillo, Mexico, to Hongkong, China, Marine Ecology Progress Series Vol. 176, page 253-262. (1999).

15. David, M. and Gollasch, S., EU shipping in the dawn of managing the ballast water issue, Marine Pollution Bulletin Vol. 56, page 1966-1972, DOI:10.1016. (2008).

16. McCollin, T., Shanks, A.M. and Dunn, J., Changes on zooplankton and diversity after ballast water exchange in regional seas, Marine Pollution Bulletin Vol. 56, page 834844, DOI:10.1016. (2008). 